\title{
Preformulation Studies on LACTUCA SATIVA as Nutraceuticals Granules
}

\author{
Nagib Ali Elmarzugia, ${ }^{*}$, Eseldin Ibrahim Keleb ${ }^{b}$, Aref Taleb Mohamed ${ }^{b}$, Mohamed Salamac, Mariani Abdul Hamida, Wan Rosli Wan \\ Sulaimand, Amal Muftah Hamzae, Hesham Ali El-Enshasya \\ aInstitute of Bioproduct Development, Universiti Teknologi Malaysia, 81310 UTM Johor Bahru, Johor, Malaysia \\ ${ }^{b}$ Dept. of Industrial Pharmacy, Faculty of Pharmacy, Tripoli University, Tripoli, Libya \\ 'Faculty of Pharmacy, Universiti Teknologi Mara, Malaysia \\ ${ }^{d}$ Faculty of Petroleum and Renewable Energy, Universiti Teknologi Malaysia, 81310 UTM Johor Bahru, Johor, Malaysia \\ eNational Medical Research Center, NASR, Alzawia, Libya \\ *Corresponding author: nagib@ibd.utm.my
}

\section{Article history}

Received :29 July 2013

Received in revised form :

23 September 2013

Accepted :29 September 2013

Graphical abstract

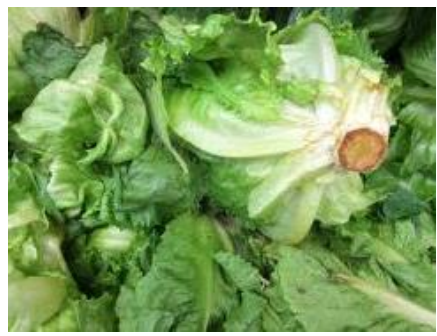

\section{Abstract}

The utilization of natural products for their pharmaceutical and nutraceuticals purposes have high value in prevention and treatment of myriad illness. In pharmaceutical industry the formulation of natural products into an effective and stable dosage form necessitate evaluation of the processing techniques required and the properties of the product obtained. Therefore the objective of the present study was to prepare and evaluate lettuce leaves Lactuca sativa granules in a view to develop solid dosage forms. Lettuce leaves were washed with water, one batch was dried in open air and the other one in oven and grinded into fine powder. Dried powdered lettuce leaves were granulated without and with polyvinylpyrrolidone (PVP) at various water concentrations. The prepared granules were evaluated for its particle size distribution, bulk density, tapped density, hausners index, Carr's index, friability, flowability and water absorption. The influence of water concentration, PVP addition and drying methods on the granule properties were also investigated. The results obtained showed that lettuce granules possess good flow properties and can be used as a candidate for the formulation of solid dosage forms particularly tablets.

Keywords: Preformulation; Lactuca Sativa, granules; nutraceuticals; flow properties

\begin{abstract}
Abstrak
Penggunaan produk-produk semulajadi untuk tujuan farmaseutikal dan nutraseutikal mempunyai nilai yang tinggi dalam membasmi dan merawat pelbagai penyakit. Dalam industri farmaseutikal, formulasi produk-produk semulajadi ke dalam bentuk dos yang stabil dan berkesan memerlukan penilaian terhadap aspek pemprosesan yang diperlukan dan ciri-ciri produk yang diperolehi. Justeru, objektif kajian ini adalah untuk menyediakan dan mengkaji butiran dari daun salad (Lactuca sativa) secara keseluruhan bagi menghasilkan produk dalam bentuk dos pepejal. Daun salad dibersihkan dengan air, sebahagian dikeringkan dengan udara sekeliling dan sebahagian dikeringkan dalam ketuhar seterusnya dikisar menjadi serbuk halus. Serbuk daun salad kering dijadikan butiran dengan menggunakan polyvinylpyrrolidone (PVP) dan tanpa PVP pada kepekatan air yang pelbagai. Butiran-butiran yang telah disediakan dikaji dari segi penyebaran saiz partikel, ketumpatan pukal, ketumpatan pejal, index hausners, index Carr's, kebolehkecilan, kebolehaliran dan penyerapan air. Pengaruh kepekatan air, penambahan PVP dan cara pengeringan ke atas ciri-ciri butiran turut dikaji. Hasil yang diperolehi menunjukkan butiran daun salad menjurus kepada ciri-ciri alir dan boleh digunakan sebagai bahan untuk formulasi bentuk pepejal terutamanya kapsul.
\end{abstract}

Kata kunci: Pra-formulasi; Lactuca Sativa; butiran; nutraseutikal; sifat aliran

C 2013 Penerbit UTM Press. All rights reserved.

\subsection{INTRODUCTION}

Traditional medicine is well known science world-wide for the treatment of various diseases. Formulations composed from plant parts for curing some common illnesses are well known since a long time. Most of these formulations are processed in a way that does not take into consideration the basic principle that should be followed during formulation and processing of such traditional dosage forms. Further some of these formulations are conducted in non-hygienic conditions, which could result in serious defects in the formulation. ${ }^{1-2}$ In recent years, consumers have begun to look at food not only for basics nutrition, but also for health benefits. Development of nutraceuticals necessitates further investigation on plants that have some therapeutic values beside its nutritional value in order to present them in a formulation that can be safely and effectively applied and used. ${ }^{3}$

Garden lettuce Lactuca sativa, belonging to the Asteraceae family, is an important leafy vegetable known for its medicinal properties. It is grown mostly as cold weather crop but can also be 
grown in spring or early summers. A monthly mean temperature of $13-16{ }^{\circ} \mathrm{C}$ is considered ideal for its growth. ${ }^{4}$ in many countries; it is typically eaten cold, raw, in salads, sandwiches, hamburgers, tacos and in many other dishes. Lettuce is a fat free, low calorie food and is good for a well balanced diet. It is a valuable source of vitamin $\mathrm{A}$ and folic acid. ${ }^{5}$

The food substances used as nutraceuticals contain antioxidants, prebiotics, probiotics, certain photochemical, and pectin, which lower cholesterol, or fiber, and reduce the risk of colon cancer too. ${ }^{6-7}$

The whole Lactuca sativa plant has been used in the treatment of stomach problems to stimulate digestion, to enhance appetite and relieve inflammation ${ }^{8}$ via the anti-inflammatory activities of triterpene lactones. ${ }^{9}$ Lactuca sativa gives protection against $D$-galactose-induced oxidative stress and reduces accumulation of lipofuscin granules. ${ }^{10}$ Lactuca sativa is known to be rich in antioxidants viz. quercetin, caffeic acid, vitamin $C$, carotenoids, and phytols. ${ }^{11-12}$ The major components present in Lactuca sativa extract are 15-oxalyl and 8-sulfate conjugates of the guaianolide sesquiterpene lactones, lactucin, deoxylactucin, and lactucopicrin. ${ }^{13}$ The antioxidant activity of Lactuca sativa has been reported to prevent chronic diseases related to oxidative stress such as cancer. Antioxidant activity of lettuce leaves has been reported that would prevent chronic diseases related to oxidative stress such as cancer. ${ }^{14}$ In addition to antioxidant, antibacterial and antiviral effect has been observed in its extract which make it easily accessible source for food supplement or in pharmaceutical industry. ${ }^{15-16-17}$

Lettuce leaves are found to have antioxidant, heamatinic, hypnotic stomachic, galactagogue, improve appetite, purify the blood, burning sensation, headache, trouble of nose, in scabies, leucoderma, ophthalmia, liver diseases. ${ }^{18}$ Lactucarium ("Lettuce Opium") is a mild opiate-like substance that is contained in all types of lettuce. Sesquiterpenoid lactones were isolated from lettuce include constitutive components of latex such as lactucin, guanine-type sesquiterpene glycoside, lactusidec $\left(\mathrm{C}_{21} \mathrm{H}_{28} \mathrm{O}_{9}\right)$ along with lactuside $\mathrm{A}$, macrocliniside $\mathrm{A}$ and lactupicrin. ${ }^{19-20-21}$ Immune detection revealed multiple protein types in young leaves of Lettuce. ${ }^{22-23}$

Anticonvulsant and sedative-hypnotic effects have been mentioned for the leaves of plant, ${ }^{24}$ the study of effect on behavioral and locomotor activity has shown no noticeable response and no lethality was observed up to the dose of $6 \mathrm{~g} / \mathrm{kg} .{ }^{25-8}$ Moreover, the exposure of lettuce leaves to cytotoxic, carcinogenic and mutagenic elements of Cadmium has been assessed and provided no mutagenic and genetic instability were found. ${ }^{26-24-27-28}$

Considering the varied beneficial activities reported in the traditional system of medicine as well as the recent reports, Lactuca sativa was selected plant to prepare and evaluate several Preformulation studies for pharmaceutical and nutraceutical industry as granules in a view to develop solid dosage form.

\subsection{EXPERIMENTAL}

\subsection{Materials}

Fresh garden lettuce leaves were purchased from the local market. Polyvinylpyrrolidone (PVP) was obtained from BDH Chemical (Poole, England). Double distilled water was used throughout the study. All chemicals and reagents were of analytical grade.

\subsection{Methods}

\subsubsection{Drying of Lettuce Leaves}

Lettuce leaves were properly cleaned with water, one batch was dried in open air and the other in oven at $50{ }^{\circ} \mathrm{C}$ for 6 hours.

\subsubsection{Preparation of Granules}

Lettuce leave granules were prepared without PVP and with various concentrations of PVP (1.25 and 2.5\% dry addition). Water (in different concentration was added gradually to the dried leaves powder with continuous wet massing. Following liquid addition the wet mass was sized into granules in oscillating granulator (Erweka, Germany) at speed 3 using $1 \mathrm{~mm}$ screen.

The distance between screen and rotor was kept constant. The obtained granules were dried in open air for one batch and in oven at $40{ }^{\circ} \mathrm{C}$ for hours for another batch.

\subsubsection{Evaluation of Granules}

The prepared granules were evaluated for its particle size distribution, bulk density, tapped density, hausners index, Carr's index, friability, flowability and water absorption $(2,14)$.

\subsubsection{Particle Size Measurement with Sieve Method}

The particle size distribution of all samples was determined by sieve analysis (Ritsch, Strasse, Germany) using the sieve No. 14, $18,25,35,60,120$ in a series. The samples were subjected to vibration using sieve vibrator (Ritsch, Strasse, Germany) for certain period of time.

\subsubsection{Angle of Repose}

The static angle of repose, a, was measured according to the fixed funnel and free standing cone method. A funnel was clamped with its tip $2 \mathrm{~cm}$ above a graph paper placed on a flat horizontal surface. The powders were carefully poured through the funnel until the apex of the cone thus formed just reached the tip of the funnel.

The mean diameters of the base of the powder cones were determined and the tangent of the angle of repose calculated using the equation:

$$
\text { Tan } \mathrm{a}=2 \mathrm{~h} / \mathrm{D}
$$

\subsubsection{Granule Friability}

The granule friability was determined in a friabilator (Germany), at a speed of $25 \mathrm{rpm}$ for $10 \mathrm{~min}$, by subjecting $10 \mathrm{~g}$ of granules together with 200 glass beads (mean diameter $4 \mathrm{~mm}$ ) to falling shocks. The glass beads were then removed and the weight of granules retained was determined after vibrating for $5 \mathrm{~min}$ (Retsch, Germany).

The friability was calculated as $\left\{\left(\mathrm{I}_{\mathrm{wt}}-\mathrm{F}_{\mathrm{wt}}\right) / \mathrm{I}_{\mathrm{wt}}\right\} * 100$. Where $I_{w t}$ is initial weight and $F_{w t}$ is final weight of the granules

\subsubsection{Bulk and Tapped Densities}

The bulk volume (Vo) of $50 \mathrm{~g}$ granules was recorded in a $100 \mathrm{ml}$ measuring cylinder as well as the volume after taping till constant volume. Bulk and tapped densities in $\mathrm{g} / \mathrm{ml}$ were calculated as $50 / V_{0}$ and $50 / \mathrm{V}_{\mathrm{f}}$, respectively. 


\subsubsection{Hausners Index}

This was calculated as the ratio of tapped density to the bulk density of the samples.

\subsubsection{Carr's Index}

The compressibility index $(\mathrm{C} \%)$ was calculated from the bulk and tapped density using the equation $\mathrm{C} \%=\left\{\left(\rho_{f-} \rho_{i}\right) / \rho_{f}\right\} * 100$ Where $\rho_{i}$ is the bulk density and $\rho_{f}$ is the tapped density.

\subsubsection{Water Absorption}

A sample of $5 \mathrm{~g}$ granules was put on the top of filter paper and placed in the funnel then $20 \mathrm{ml}$ distilled water was added to the sample. The excess water was filtered and the amount of water absorbed was calculated in time interval of 5, 15, 30, 45, 60 min. The actual water absorption was calculated by subtracting the weight of the wet filter paper and the weight of the sample.

\subsection{RESULTS AND DISCUSSION}

The properties of air dried and oven dried lettuce leaves granules prepared without and with PVP are listed in table 1 and 2 respectively. The results obtained showed that the friability of oven dried granules ranged between 0 and $0.7 \%$ indicating good granule friability whereas much higher friability was observed for air dried samples granulated without PVP and with 1.25\% PVP. However, increasing PVP concentration to $2.5 \%$ resulted in granule friability similar to those formulations proceed in oven. The angle of repose in both air dried and oven dried granules was about less than $30^{\circ}$ for formulations prepared at lower water concentration indicating good flow properties but it started increasing as water concentration increased or when PVP was included in the formulation.

The Hausners index and Carr's index of air dried and oven dried granules was found to be 1 to 1.27 and below 15 respectively suggesting excellent flowability of the granules.

Particle size analysis of air dried and oven dried lettuce granules prepared without PVP and with PVP at various water concentrations is shown in Figure 1 to Figure 12. The results showed that as water concentration increased and no PVP involved, the air dried granules fraction between 855 to $2000 \mu \mathrm{m}$ increased. Similar results were obtained for oven dried granules However, incorporation of PVP resulted in increased air dried as well as oven dried granules fraction between 855 and $2000 \mu \mathrm{m}$ at much lower water concentrations.

Figure legend particle size analysis $(\mu \mathrm{m})$ of lettuce powder granulated at different water concentrations (air drying).

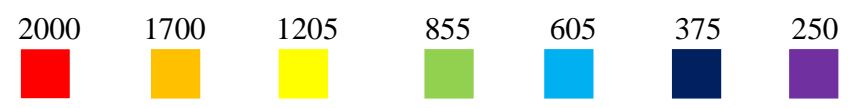

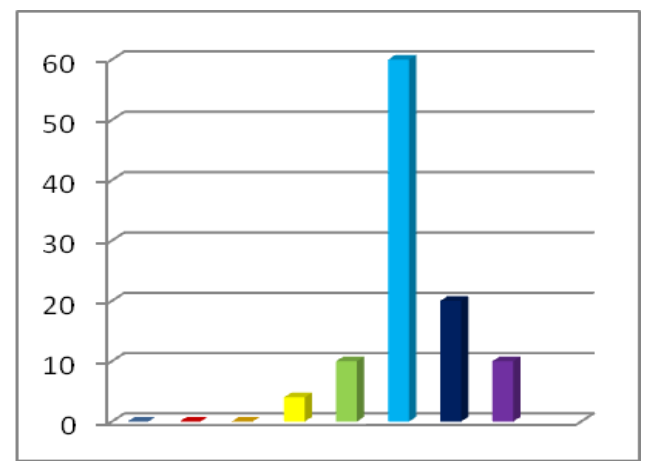

Figure $127 \%$ degree of repose for no PVP (air drying)

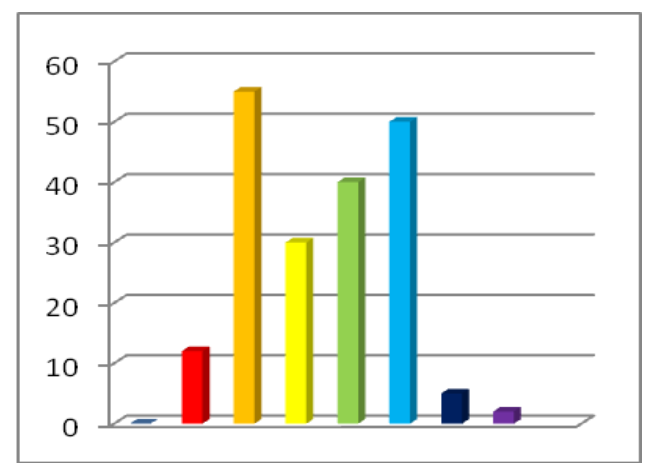

Figure 2 60\% degree of repose for no PVP (air drying)

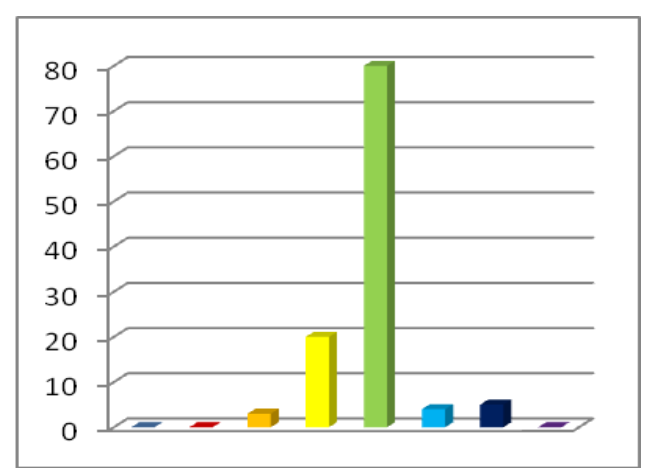

Figure $330 \%$ degree of repose for 1.25\% PVP (air drying)

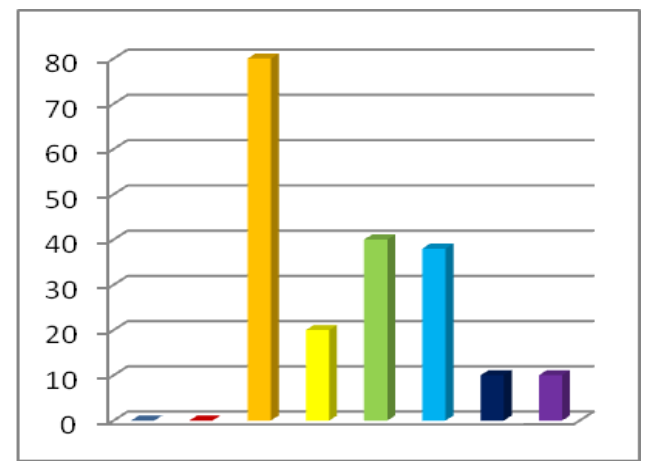

Figure 4 60\% degree of repose for 1.25\% PVP (air drying) 


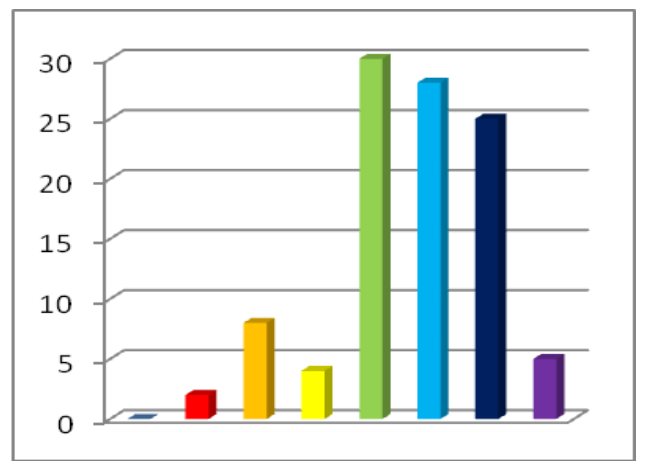

Figure $530 \%$ degree of repose for 2.5\% PVP (air drying)

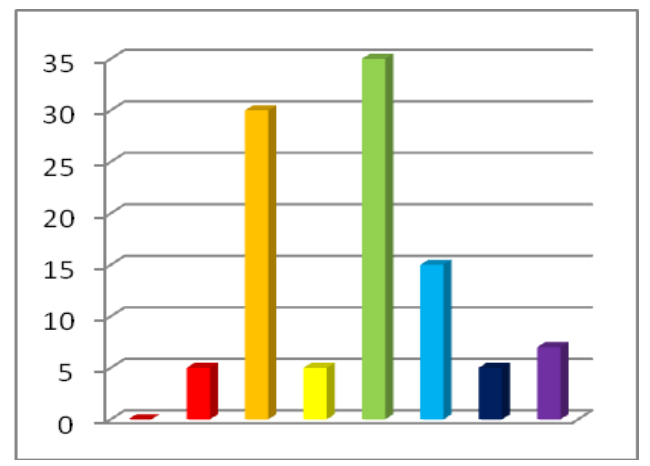

Figure 6 60\% degree of repose for 2.5\% PVP (air drying)

Table 1 Influence of formulation parameters on the properties of dried lettuce leaves granules (air drying)

\begin{tabular}{cccccccc}
\hline $\begin{array}{c}\text { Water } \\
(\%)\end{array}$ & $\begin{array}{c}\text { PVP } \\
(\boldsymbol{\%})\end{array}$ & $\begin{array}{c}\text { Bulk density } \\
(\mathbf{g} / \mathbf{c c})\end{array}$ & $\begin{array}{c}\text { Tapped } \\
\text { density } \\
(\mathbf{g} / \mathbf{c c})\end{array}$ & $\begin{array}{c}\text { Hausners } \\
\text { index }\end{array}$ & $\begin{array}{c}\text { Carr's } \\
\text { index }\end{array}$ & $\begin{array}{c}\text { Friability } \\
(\boldsymbol{\%})\end{array}$ & $\begin{array}{c}\text { Angle of } \\
\text { repose } \\
\left({ }^{\circ}\right)\end{array}$ \\
\hline 27 & 0 & 0.27 & 0.72 & 2.67 & 62.5 & 6.71 & 27.02 \\
50 & 0 & 0.58 & 0.58 & 1 & 0 & 27.3 & 26.1 \\
55 & 0 & 0.53 & 0.54 & 1.02 & 1.85 & 47.2 & 27.47 \\
60 & 0 & 0.44 & 0.46 & 1.05 & 4.35 & 29 & 26.57 \\
30 & 1.25 & 0.42 & 0.46 & 1.1 & 8.7 & 41.4 & 26.57 \\
40 & 1.25 & 0.3 & 0.33 & 1.1 & 9.09 & 48.2 & 27.47 \\
50 & 1.25 & 0.27 & 0.29 & 1.07 & 6.9 & 50.2 & 29.25 \\
60 & 1.25 & 0.36 & 0.36 & 1 & 0 & 22.8 & 28.37 \\
30 & 2.5 & 0.3 & 0.3 & 1 & 0 & 0.4 & 25.17 \\
40 & 2.5 & 0.28 & 0.31 & 1.11 & 9.68 & 1 & 25.64 \\
50 & 2.5 & 0.29 & 0.3 & 1.03 & 3.33 & 0.2 & 28.81 \\
60 & 2.5 & 0.26 & 0.29 & 1.12 & 10.34 & 0.1 & 33.42 \\
\hline
\end{tabular}

Table 2 Influence of formulation parameters on the properties of dried lettuce leaves granules (Oven drying)

\begin{tabular}{cccccccc}
\hline $\begin{array}{c}\text { Water } \\
(\%)\end{array}$ & $\begin{array}{c}\text { PVP } \\
(\%)\end{array}$ & $\begin{array}{c}\text { Bulk density } \\
(\mathbf{g} / \mathbf{c c})\end{array}$ & $\begin{array}{c}\text { Tapped } \\
\text { density }(\mathbf{g} / \mathbf{c c})\end{array}$ & $\begin{array}{c}\text { Hausners } \\
\text { index }\end{array}$ & $\begin{array}{c}\text { Carr's } \\
\text { index }\end{array}$ & $\begin{array}{c}\text { Friability } \\
(\boldsymbol{\%})\end{array}$ & $\begin{array}{c}\text { Angle of } \\
\text { repose } \\
\left({ }^{\circ}\right)\end{array}$ \\
\hline 27 & 0 & 0.29 & 0.34 & 1.17 & 14.71 & 0.6 & 25.17 \\
50 & 0 & 0.23 & 0.25 & 1.09 & 8 & 0.7 & 25.17 \\
55 & 0 & 0.22 & 0.28 & 1.27 & 21.43 & 0.6 & 34.61 \\
60 & 0 & 0.22 & 0.23 & 1.05 & 4.35 & 0 & 29.25 \\
30 & 1.25 & 0.14 & 0.16 & 1.14 & 12.5 & 0 & 33.42 \\
40 & 1.25 & 0.23 & 0.25 & 1.09 & 8 & 0 & 36.13 \\
50 & 1.25 & 0.24 & 0.26 & 1.08 & 7.69 & 0 & 36.87 \\
60 & 1.25 & 0.19 & 0.21 & 1.11 & 9.52 & 0 & 30.96 \\
30 & 2.5 & 0.14 & 0.15 & 1.07 & 6.67 & 0 & 26.57 \\
40 & 2.5 & 0.15 & 0.18 & 1.2 & 16.67 & 0.2 & 28.37 \\
50 & 2.5 & 0.19 & 0.19 & 1 & 0 & 0 & 28.81 \\
60 & 2.5 & 0.25 & 0.25 & 1 & 0 & 0 & 33.21 \\
\hline
\end{tabular}




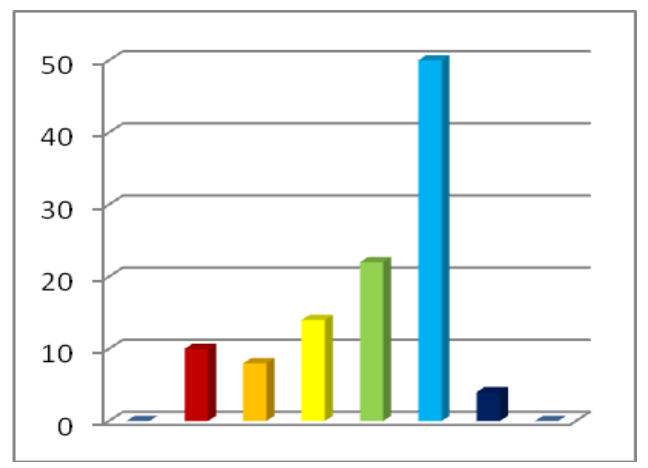

Figure 7 27\% degree of repose for no PVP (oven drying)

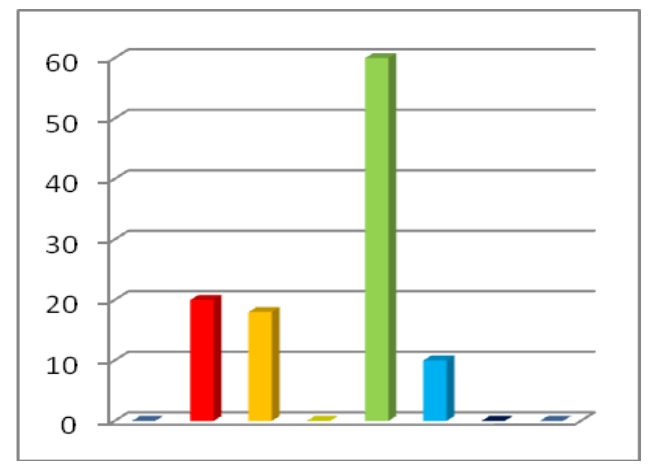

Figure $930 \%$ degree of repose for $1.25 \%$ PVP (oven drying)

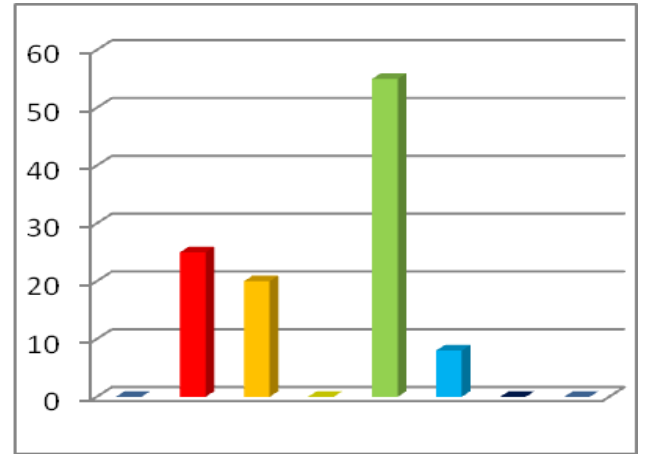

Figure 11 30\% degree of repose for 2.5\% PVP (oven drying)

Weight-size distributions of granules as measured by U.S Standard Sieves for different weights of granules and at different times are listed in table 3 to 10 . It was found that average diameter of the granules decreased as the time of sieving increased for different weights to be sieved. However for $350 \mathrm{gm}$ granules to be sieved there was no significant decrease in average diameter with time as there was with $50 \mathrm{~g}, 150 \mathrm{~g}$, and $250 \mathrm{~g}$. It could be attributed to the load of granules per unit area of sieves influences the sieving.

The results obtained from water absorption experiment are shown in figure 13 to 16 . The result indicated that the best water absorption was obtained for air dried and oven dried granules prepared without PVP at 55\% and 60\% concentration respectively and the amount absorbed was retained by the granules for almost one hour. However with addition of PVP the best water absorption was achieved at 50\% (for dried samples) and $40 \%$ (for oven dried samples).

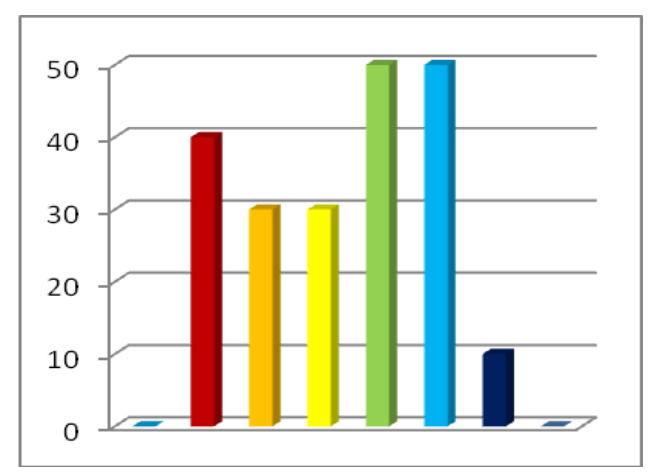

Figure $850 \%$ degree of repose for no PVP (oven drying)

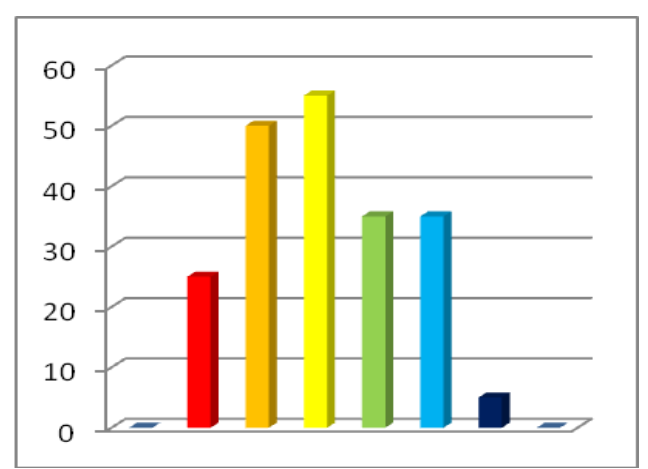

Figure $1060 \%$ degree of repose for $1.25 \%$ PVP (oven drying)

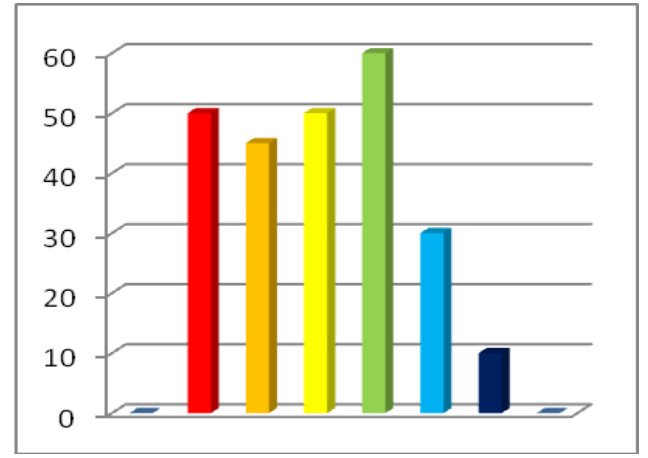

Figure 12 60\% degree of repose for 2.5\% PVP (oven drying)

\subsection{CONCLUSION}

The findings of the study have provided wide range of Preformulation basic information in order to make Lactuca sativa in granules solid dosage form at different conditions, with considerable low cost natural source. Moreover, it concludes that lettuce granules possess good flow properties and can be applied and used as a potential candidate for the pharmaceutical and nutraceutical formulation of solid dosage forms particularly tablets and granules. 
Table 3 Weight-size distribution of granular lettuce leaves powder as measured by US standard Sieves (Weight of granules $=50 \mathrm{~g}$; Time $=5 \mathrm{~min}$ ). Average diameter $=65324.75 / 100=653.25 \mu \mathrm{m}$

\begin{tabular}{ccccc}
\hline $\begin{array}{c}\text { Sieve Number } \\
\text { (Passed/Retained) }\end{array}$ & $\begin{array}{c}\text { Arithmetic Mean Size of } \\
\text { Openings }(\boldsymbol{\mu m})\end{array}$ & $\begin{array}{c}\text { Weight Retained on } \\
\text { smaller sieve }\end{array}$ & $\begin{array}{c}\text { \% Retained on Smaller } \\
\text { sieve }\end{array}$ & Weight size \\
\hline 1 & 2 & 3 & 4 & $2 \times 4$ \\
$14 / 18$ & 1205 & 9.97 & 19.94 & 24027.7 \\
$18 / 25$ & 855 & 10.1 & 20.2 & 17271 \\
$25 / 35$ & 605 & 10.63 & 21.26 & 12862.3 \\
$35 / 60$ & 375 & 10.47 & 20.94 & 7852.5 \\
$60 / 120$ & 187.5 & 8.83 & 17.66 & 3311.25 \\
& & 50 & 100 & 65324.75 \\
\hline
\end{tabular}

Table 4 Weight-size distribution of granular lettuce leaves powder as measured by US standard Sieves (Weight of granules $=50 \mathrm{~g}$; Time= $15 \mathrm{~min}$ ). Average diameter $=63559.075 / 100=635.59 \mu \mathrm{m}$

\begin{tabular}{ccccc}
\hline $\begin{array}{c}\text { Sieve Number } \\
(\text { Passed/Retained) }\end{array}$ & $\begin{array}{c}\text { Arithmetic Mean Size of } \\
\text { Openings }(\boldsymbol{\mu m})\end{array}$ & $\begin{array}{c}\text { Weight Retained on } \\
\text { smaller sieve }\end{array}$ & $\begin{array}{c}\text { \% Retained on Smaller } \\
\text { sieve }\end{array}$ & Weight size \\
\hline 1 & 2 & 3 & 4 & $2 \times 4$ \\
$14 / 18$ & 1205 & 9.07 & 18.15 & 21870.75 \\
$18 / 25$ & 855 & 10.49 & 20.98 & 17937.9 \\
$25 / 35$ & 605 & 10.25 & 20.51 & 12408.55 \\
$35 / 60$ & 375 & 10.06 & 20.13 & 7548.75 \\
$60 / 120$ & 187.5 & 10.11 & 20.23 & 3793.125 \\
& & 49.98 & 100 & 63559.075 \\
\hline
\end{tabular}

Table 5 Weight-size distribution of granular lettuce leaves powder as measured by US standard Sieves (Weight of granules $=150 \mathrm{~g}$; Time $=5 \mathrm{~min}$ ). Average diameter $=65028.525 / 100=650.29 \mu \mathrm{m}$

\begin{tabular}{ccccc}
\hline $\begin{array}{c}\text { Sieve Number } \\
(\text { Passed/Retained) }\end{array}$ & $\begin{array}{c}\text { Arithmetic Mean Size of } \\
\text { Openings }(\boldsymbol{\mu m})\end{array}$ & $\begin{array}{c}\text { Weight Retained on } \\
\text { smaller sieve }\end{array}$ & $\begin{array}{c}\text { \% Retained on Smaller } \\
\text { sieve }\end{array}$ & Weight size \\
\hline 1 & 2 & 3 & 4 & $2 \times 4$ \\
$14 / 18$ & 1205 & 29.35 & 19.73 & 23774.65 \\
$18 / 25$ & 855 & 29.91 & 20.11 & 17194.05 \\
$25 / 35$ & 605 & 31.29 & 21.04 & 12729.2 \\
$35 / 60$ & 375 & 31.69 & 21.31 & 7991.25 \\
$60 / 120$ & 187.5 & 26.49 & 17.81 & 3339.375 \\
& & 148.73 & 100 & 65028.525 \\
\hline
\end{tabular}

Table 6 Weight-size distribution of granular lettuce leaves powder as measured by US standard Sieves (Weight of granules $=150 \mathrm{~g}$; Time $=15 \mathrm{~min}$ ) Average diameter $=63082.975 / 100=630.83 \mu \mathrm{m}$

\begin{tabular}{ccccc}
\hline $\begin{array}{c}\text { Sieve Number } \\
\text { (Passed/Retained) }\end{array}$ & $\begin{array}{c}\text { Arithmetic Mean Size of } \\
\text { Openings }(\boldsymbol{\mu m})\end{array}$ & $\begin{array}{c}\text { Weight Retained on } \\
\text { smaller sieve }\end{array}$ & $\begin{array}{c}\text { \% Retained on Smaller } \\
\text { sieve }\end{array}$ & Weight size \\
\hline 1 & 2 & 3 & 4 & $2 \times 4$ \\
$14 / 18$ & 1205 & 27.67 & 18.52 & 22316.6 \\
$18 / 25$ & 855 & 30.64 & 20.51 & 17536.05 \\
$25 / 35$ & 605 & 28.96 & 19.39 & 11730.95 \\
$35 / 60$ & 375 & 29.51 & 19.75 & 7406.25 \\
$60 / 120$ & 187.5 & 32.61 & 21.83 & 4093.125 \\
& & 149.39 & 100 & 63082.975 \\
\hline
\end{tabular}


Table 7 Weight-size distribution of granular lettuce leaves powder as measured by US standard Sieves (Weight of granules $=250 \mathrm{~g}$; Time $=5 \mathrm{~min}$ ). Average diameter $=64946.25 / 100=649.46 \mu \mathrm{m}$

\begin{tabular}{ccccc}
\hline $\begin{array}{c}\text { Sieve Number } \\
\text { Passed/Retained) }\end{array}$ & $\begin{array}{c}\text { Arithmetic Mean Size of } \\
\text { Openings }(\boldsymbol{\mu m})\end{array}$ & $\begin{array}{c}\text { Weight Retained on } \\
\text { smaller sieve }\end{array}$ & $\begin{array}{c}\text { \% Retained on Smaller } \\
\text { sieve }\end{array}$ & Weight size \\
\hline 1 & 2 & 3 & 4 & $2 \times 4$ \\
$14 / 18$ & 1205 & 50.17 & 20.08 & 24196.4 \\
$18 / 25$ & 855 & 49.85 & 19.94 & 17048.7 \\
$25 / 35$ & 605 & 51.55 & 20.63 & 12481.15 \\
$35 / 60$ & 375 & 51.19 & 20.49 & 7683.75 \\
$60 / 120$ & 187.5 & 47.13 & 18.86 & 3536.25 \\
& & 249.89 & 100 & 64946.25 \\
\hline
\end{tabular}

Table 8 Weight-size distribution of granular lettuce leaves powder as measured by US standard Sieves (Weight of granules $=250 \mathrm{~g}$; Time $=15 \mathrm{~min}$ ). Average diameter $=63663.6 / 100=636.64 \mu \mathrm{m}$

\begin{tabular}{ccccc}
\hline $\begin{array}{c}\text { Sieve Number } \\
(\text { Passed/Retained) }\end{array}$ & $\begin{array}{c}\text { Arithmetic Mean Size of } \\
\text { Openings }(\boldsymbol{\mu m})\end{array}$ & $\begin{array}{c}\text { Weight Retained on } \\
\text { smaller sieve }\end{array}$ & $\begin{array}{c}\text { \% Retained on Smaller } \\
\text { sieve }\end{array}$ & Weight size \\
\hline 1 & 2 & 3 & 4 & $2 \times 4$ \\
$14 / 18$ & 1205 & 47.89 & 19.16 & 23087.8 \\
$18 / 25$ & 855 & 50.88 & 20.36 & 17407.8 \\
$25 / 35$ & 605 & 48.97 & 19.6 & 11858 \\
$35 / 60$ & 375 & 48.58 & 19.44 & 7290 \\
$60 / 120$ & 187.5 & 53.57 & 21.44 & 4020 \\
& & 249.89 & 100 & 63663.6 \\
\hline
\end{tabular}

Table 9 Weight-size distribution of granular lettuce leaves powder as measured by US standard Sieves (Weight of granules $=350 \mathrm{~g}$; Time $=5 \mathrm{~min}$ ). Average diameter $=65388 / 100=653.88 \mu \mathrm{m}$

\begin{tabular}{ccccc}
\hline $\begin{array}{c}\text { Sieve Number } \\
\text { (Passed/Retained) }\end{array}$ & $\begin{array}{c}\text { Arithmetic Mean Size of } \\
\text { Openings }(\boldsymbol{\mu m})\end{array}$ & $\begin{array}{c}\text { Weight Retained on } \\
\text { smaller sieve }\end{array}$ & $\begin{array}{c}\text { \% Retained on Smaller } \\
\text { sieve }\end{array}$ & Weight size \\
\hline 1 & 2 & 3 & 4 & $2 \times 4$ \\
$14 / 18$ & 1205 & 70.5 & 20.21 & 24353.05 \\
$18 / 25$ & 855 & 69.47 & 19.91 & 17023.05 \\
$25 / 35$ & 605 & 74.25 & 21.28 & 12874.4 \\
$35 / 60$ & 375 & 72.58 & 20.8 & 7800 \\
$60 / 120$ & 187.5 & 62.11 & 17.8 & 3337.5 \\
& & 348.91 & 100 & 65388 \\
\hline
\end{tabular}

Table 10 Weight-size distribution of granular lettuce leaves powder as measured by US standard Sieves (Weight of granules $=350 \mathrm{~g}$; Time $=15 \mathrm{~min}$ ) Average diameter $=64287.825 / 100=642.88 \mu \mathrm{m}$

\begin{tabular}{ccccc}
\hline $\begin{array}{c}\text { Sieve Number } \\
\text { (Passed/Retained) }\end{array}$ & $\begin{array}{c}\text { Arithmetic Mean Size of } \\
\text { Openings }(\boldsymbol{\mu m})\end{array}$ & $\begin{array}{c}\text { Weight Retained on } \\
\text { smaller sieve }\end{array}$ & $\begin{array}{c}\text { \% Retained on Smaller } \\
\text { sieve }\end{array}$ & Weight size \\
\hline 1 & 2 & 3 & 4 & $2 \times 4$ \\
$14 / 18$ & 1205 & 69.14 & 19.77 & 23822.85 \\
$18 / 25$ & 855 & 69.71 & 19.93 & 17040.15 \\
$25 / 35$ & 605 & 70.1 & 20.04 & 12124.2 \\
$35 / 60$ & 375 & 69.97 & 20.01 & 7503.75 \\
$60 / 120$ & 187.5 & 70.82 & 20.25 & 3796.875 \\
& & 349.74 & 100 & 64287.825 \\
\hline
\end{tabular}




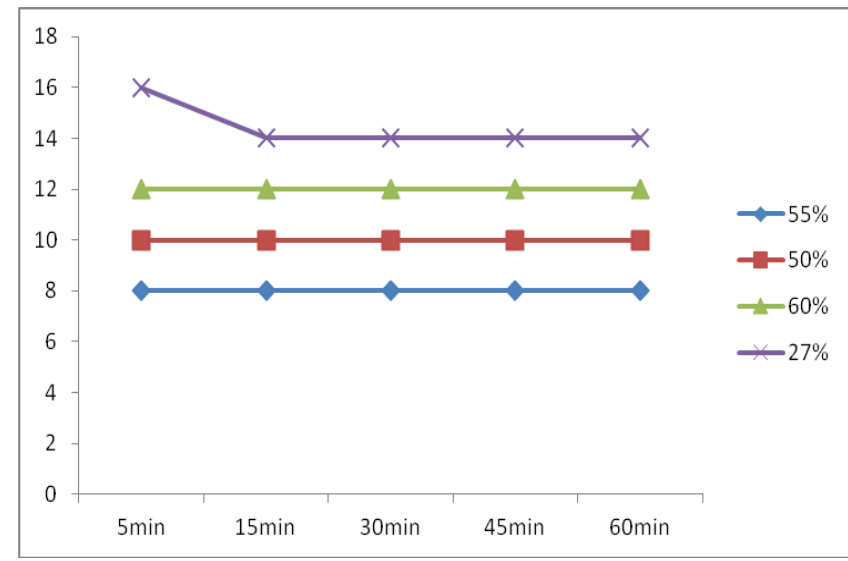

Figure 13 Influence of water concentration on water absorption of lettuce granules. No PVP (air drying)

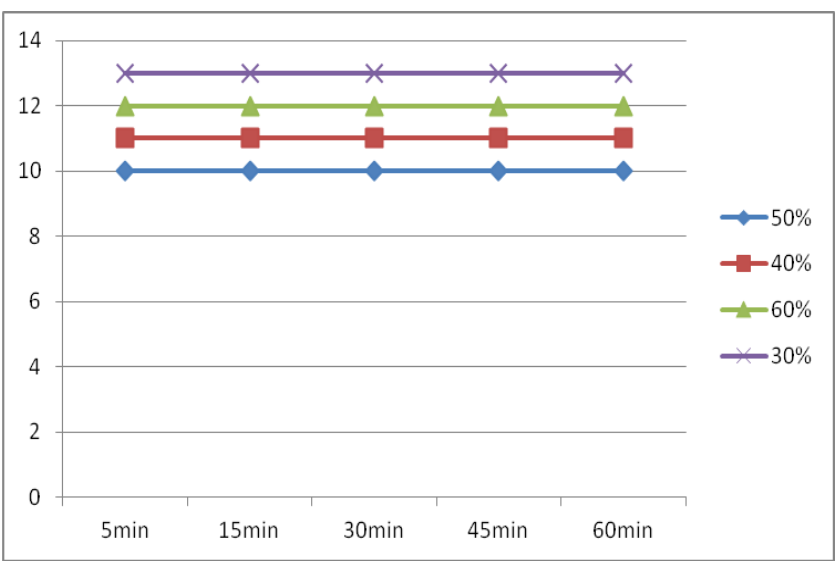

Figure 14 Influence of water concentration on water absorption of lettuce granules. With PVP (air drying)

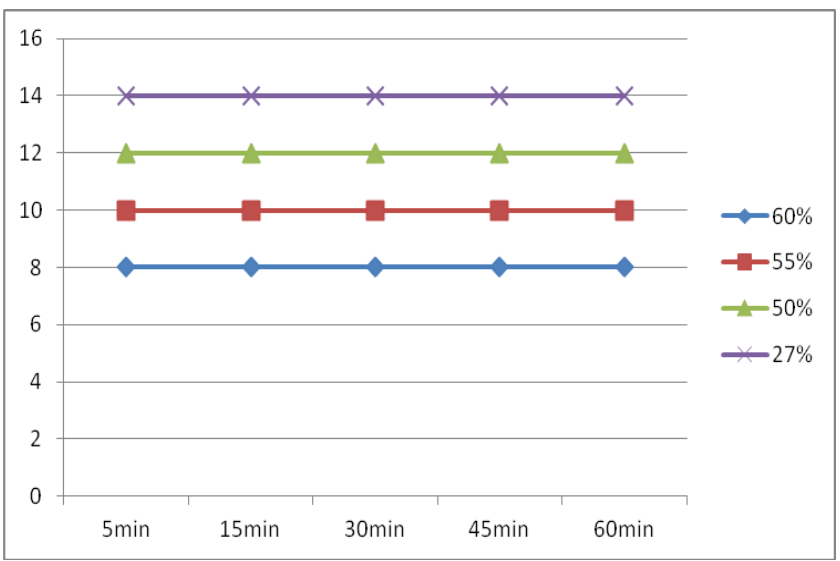

Figure 15 Influence of water concentration on water absorption of lettuce granules. No PVP (oven drying)

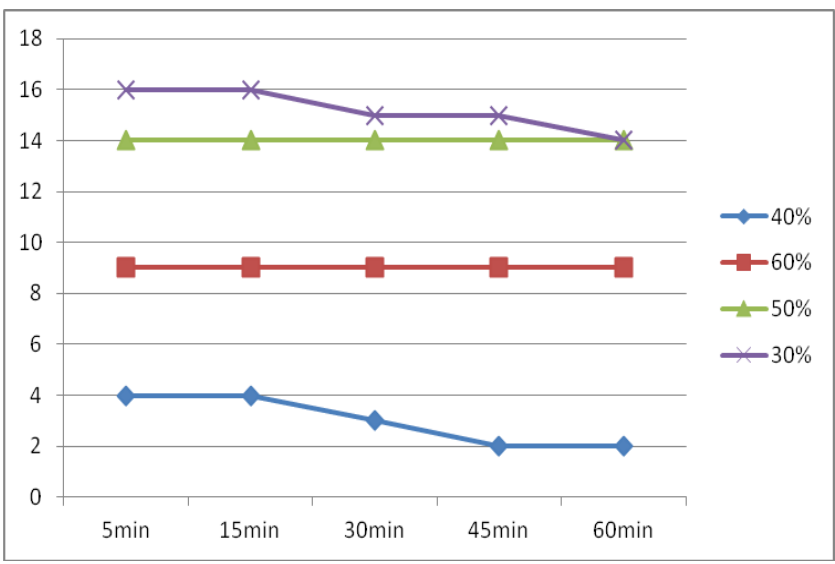

Figure 16 Influence of water concentration on water absorption of lettuce granules. With PVP (oven drying)

\section{Acknowledgement}

We are grateful for the research and technical team of Department of Industrial Pharmacy, Faculty of Pharmacy, Tripoli University.

\section{References}

11] Hancock, B. C., and Garcia-Munoz, S. 2013. How Do Formulation and Process Parameters Impact Blend and Unit Dose Uniformity? Further Analysis of the Product Quality Research Institute Blend Uniformity Working Group Industry Survey. Journal of Pharmaceutical Sciences. 102: 982-986.

[2] Tomba, E., De Martin, M., Facco, P., Robertson, J., Zomer, S., Bezzo, F., and Barolo, M. 2013. General Procedure to Aid the Development of Continuous Pharmaceutical Processes Using Multivariate Statistical Modeling-An Industrial Case Study. International Journal of Pharmaceutics. 444: 25-39.

[3] Aulton, M. E. 2002. Pharmaceutical Preformulation. In Pharmaceutics the Science of Dosage Form Design (Livingstone, C., Ed.). 2nd edition. Elsevier, Spain. 113-138.

[4] Oh, M.-M., Carey, E., and Rajashekar, C. B. 2011. Antioxidant Phytochemicals in Lettuce Grown in High Tunnels and Open Field. Hortic. Environ. Biotechnol. 52: 133-139.

[5] Kim, J., Chung, H., Cho, J., and Yoon, K. 2013. Evaluation of Models Describing the Growth of Nalidixic Acid-Resistant E. coli O157:H7 in Blanched Spinach and Iceberg Lettuce as a Function of Temperature, International Journal of Environmental Research and Public Health. 10: 2857-2870.

[6] Nagib, E., Hesham, E. E., Elsayed, E., Aref, T., Ezzedin, K., Suhaila, N. Otman, E., and Nor Zalina, O. 2013. Production of $\alpha$-amylase using New Strain of Bacillus Polymyxa Isolated from Sweet Potato. IOSR Journal of Pharmacy and Biological Sciences. 5: 73-79.

[7] Hardy, G., Hardy, I., and Ball, P. A. 2003. Nutraceuticals-a Pharmaceutical Viewpoint: Part II, Current Opinion in Clinical Nutrition and Metabolic Care. 6: 661-671.

[8] Sayyah, M., Hadidi, N., and Kamalinejad, M. 2004 Analgesic and AntiInflammatory Activity of Lactuca sativa Seed Extract in Rats. Journal of Ethnopharmacology. 92: 325-329.

[9] Araruna, K., and Carlos., B. 2010. Anti-inflammatory Activities of Triterpene Lactones from Lactuca sativa. Phytopharmacology. 1: 1-6.

[10] Ambikar, D. B., Harle., U. N., Khandare., R. A., Bore., V., and Vyawahare., N. S. 2010. Neuroprtective Effect of Hydroalcoholic Extract of Dried Fruits of Trapa bispinosa Roxb on Lipofuscinogenesis and Fluorescence Product in Brain of D-galactose Induced Ageing Accelerated Mice. Indian Journal of Experimental Biology. 48: 378-382.

[11] Brunk, U. T., and Terman, A. 2002. The Mitochondrial-lysosomal Axis Theory of Aging. European Journal of Biochemistry. 269: 1996-2002.

[12] Kim, H.-J., Fonseca, J. M., Choi, J.-H., and Kubota, C. 2007. Effect of Methyl Jasmonate on Phenolic Compounds and Carotenoids of Romaine Lettuce (Lactuca sativa L.); Journal of Agricultural and Food Chemistry. 55: 10366-10372. 
[13] Sessa, R. A., Bennett, M. H., Lewis, M. J., Mansfield, J. W., and Beale, M. H. 2000. Metabolite Profiling of Sesquiterpene Lactones from Lactuca Species: Major Latex Components are Novel Oxalate and Sulfate Conjugates of Lactucin and Its Derivatives. Journal of Biological Chemistry. 275: 26877-26884.

[14] Chu, Y.-F., Sun, J., Wu, X., and Liu, R. H. 2002. Antioxidant and Antiproliferative Activities of Common Vegetables. Journal of Agricultural and Food Chemistry. 50: 6910-6916.

[15] Boivin, D., Lamy, S., Lord-Dufour, S., Jackson, J., Beaulieu, E., Côté, M., Moghrabi, A., Barrette, S., Gingras, D., and Béliveau, R. 2009. Antiproliferative and Antioxidant Activities of Common Vegetables: A Comparative Study. Food Chemistry. 112: 374-380.

[16] Edziri, H. L., Smach, M. A., Ammar, S., Mahjoub, M. A., Mighri, Z., Aouni, M., and Mastouri, M. 2011. Antioxidant, Antibacterial, and Antiviral Effects of Lactuca Sativa Extracts. Industrial Crops and Products. 34: 1182-1185.

[17] Pérez-López, U., Miranda-Apodaca, J., Muñoz-Rueda, A., and MenaPetite, A. 2013. Lettuce Production and Antioxidant Capacity are Differentially Modified by Salt Stress and Light Intensity Under Ambient And Elevated CO2. Journal of Plant Physiology.

[18] Llorach, R., Tomás-Barberán, F. A., and Ferreres, F. 2004. Lettuce and Chicory Byproducts as a Source of Antioxidant Phenolic Extracts. Journal of Agricultural and Food Chemistry. 52: 5109-5116.

[19] Han, Y. F., Cao, G. X., and Xia, M. 2009. Two New Eudesmane Sesquiterpenes from Lactuca sativa var. anagustata L. Chinese Chemical Letters. 20: 1211-1214

[20] DuPont, M., Mondin, Z., Williamson, G., and Price, K. 2000. Effect of Variety, Processing, and Storage on the Flavonoid Glycoside Content and Composition of Lettuce and Endive. Journal of Agricultural and Food Chemistry. 48: 3957-3964.
[21] Bennett, M. H., Mansfield, J. W., Lewis, M. J., and Beale, M. H. 2002 Cloning and Expression of Sesquiterpene Synthase Genes from Lettuce (Lactuca sativa L.). Phytochemistry. 60: 255-261.

[22] Legarrea, S., Betancourt, M., Plaza, M., Fraile, A., García-Arenal, F., and Fereres, A. 2012. Dynamics of Nonpersistent Aphid-borne Viruses in Lettuce Crops Covered with UV-absorbing Nets. Virus Research. 165: 18.

[23] Serafini-Fracassini, D., Di Sandro, A., and Del Duca, S. 2010. Spermine Delays Leaf Senescence in Lactuca Sativa And Prevents The Decay Of Chloroplast Photosystems. Plant Physiology and Biochemistry. 48: 602611.

[24] Monteiro, M., Santos, C., Mann, R. M., Soares, A. M. V. M., and Lopes, T. 2007. Evaluation of cadmium genotoxicity in Lactuca sativa L. using Nuclear Microsatellites. Environmental and Experimental Botany. 60: 421-427.

[25] Harsha, S. N., and Anilakumar, K. R. 2012. Effects of Lactuca sativa Extract on Exploratory Behavior Pattern, Locomotor Activity and Anxiety in Mice. Asian Pacific Journal of Tropical Disease 2 Supplement 1. S475-S479.

[26] Andrade, L. F., Davide, L. C., and Gedraite, L. S. 2010. The Effect of Cyanide Compounds, Fluorides, Aluminum, and Inorganic Oxides Present in Spent Pot Liner on Germination and Root Tip Cells of Lactuca Sativa. Ecotoxicology and Environmental Safety. 73: 626-631.

[27] Smith, S. R. 2009. A Critical Review of the Bioavailability and Impacts of Heavy Metals in Municipal Solid Waste Composts Compared to Sewage Sludge. Environment International. 35: 142-156.

[28] Matés, J. M., Pérez-Gómez, C., de Castro, I. N., Asenjo, M., and Márquez, J. 2002. Glutamine and its Relationship with Intracellular Redox Status, Oxidative Stress and Cell Proliferation/Death. The International Journal of Biochemistry \& Cell Biology. 34: 439-458. 